\title{
THE EFFECT OF ROA, FDR, AND NPF ON THE PROFIT-SHARING RATE FOR MUDHARABAH DEPOSIT IN BPRS, INDONESIA
}

\author{
Hurin 'In Pujiastutik'1), Agus Sumanto*2) \\ $(1,2)$ Faculty of Economy, Universitas Negeri Malang \\ E-mail : agus.sumanto.fe@um.ac.id ${ }^{* 2}$
}

\begin{abstract}
Until now, Islamic banking has grown very rapidly. This can be seen from the number of Islamic products that continue to grow and develop. One of them is mudharabah deposit. The profit-sharing rate that is characteristic of mudharabah deposits is the public's appeal to deposit their funds in banks, especially mudharabah deposit products. This study aims to determine the effect of financial ratios on the profit sharing rate of BPRS mudharabah deposits in Indonesia. The population used is the monthly financial reports of all BPRS in Indonesia from January 2012 to April 2018 in the form of time series data. The variables used in this study are Return on Assets (ROA), Financing to Deposit Ratio (FDR), and Non Performing Financing (NPF) as independent variables, and the profit sharing rate of mudharabah deposits from Bank Pembiayaan Rakyat Syariah (BPRS) as the dependent variable. Simultaneously, the variables ROA, FDR, and NPF together have a significant effect on the profit sharing of BPRS mudharabah deposits in Indonesia. Meanwhile, partially ROA has no significant effect on the profit sharing of BPRS mudharabah deposit in Indonesia. The FDR has a positive and significant effect on the profit sharing of the mudharabah deposits of Islamic rural banks in Indonesia. As well as NPF has a negative and significant effect on the profit sharing of mudharabah deposits in BPRS in Indonesia.
\end{abstract}

Key words: Return on Asset (ROA), Financing to Deposit Ratio (FDR), Non Performing Financing (NPF), Bank Pembiayaan Rakyat Syariah (BPRS)

\section{INTRODUCTION}

$\mathcal{U}$ ntil now, the Islamic economy in Indonesia has grown quite rapidly. The start of the development of the sharia economy was marked by the emergence of a sharia financial institution, namely Muamalat bank since 1991 which officially operated on May 1, 1992. In the 2013 Islamic banking statistical report from January to July, it was stated that the acquisition of Third Party Funds (TPF) came from Current accounts with an average of IDR 15,733.57 billion, savings with an average of IDR 47,105.14 billion, and deposits with an average of IDR 95,630.71 billion. compared to current accounts and savings. The high amount of deposits on deposits indicates that there are quite a number of customers who are more interested in time deposit products (time deposits).

Assets or capital must not produce from themselves, but must be made by human efforts. In Islamic economics, interest is stated as usury which is prohibited by Islamic 
law (Naf'an, 2014: 81). The wisdom of the prohibition of usury and the imposition of zakat is to encourage economic activity, turnover funds and reduce speculation and hoarding. Interest has caused further distance between development and the goals to be achieved and destroying the goals that are to be achieved for economic growth, productivity and economic stability (Chapra in Naf'an, 2014: 81).

Along with the continued development of Islamic banking, especially in Indonesia, studies and researches on Islamic banking have been carried out. However, there are also many differences in the results of the research conducted. In addition, according to a member of PP Masyarakat Ekonomi Syariah (MES), Abdul Muid Badrun, stated that the development of Islamic banking in Indonesia is still limited to "packaging" not "content". This can be explained from the relationship between the enthusiasm (passion) of society in Muslim fashion (Muslim fashion), diet (halah foods), the number of religious films, etc. are not directly proportional to the increase in Islamic banking assets, one of which is due to the lack of public interest in Islamic banking (Republika, 2015). According to the main director of BPRS Harta Insan Karimah (HIK), Khusnul Khorip, stated that BPRS must have a strategy to attract the public, one of which is by providing higher profit sharing to depositors compared to BUS. This is because if there is no advantage over deposits, the BPRS will be unable to compete (Republika, 2013). Based on the explanation above, the writer would like to conduct research with the title "The Effect of ROA, FDR, and NPF on the Profit-Sharing Rate for Mudharabah Deposit in BPRS, Indonesia".

\section{LITERATURE REVIEW}

\section{BPRS}

In Law no. 21 of 2008 concerning Islamic banking, states that a bank is a business entity that collects funds from the public in the form of savings and distributes them to the public in the form of credit and / or in other forms in order to improve the people's standard of living. Meanwhile, the definition of a sharia bank is a bank that carries out business activities based on sharia principles and according to its type consists of Islamic commercial banks and Islamic public financing banks Bank Pembiayaan Rakyat Syariah (BPRS) is a sharia bank which in its activities does not provide services in payment traffic.

The objectives of the establishment of the BPRS are as follows: (Perwataadmadja \& Antonio in Lubis \& Wajdi, 2012: 72)

1. To improve the economic welfare of Muslims, especially economically weak people who are generally in rural areas.

2. Increase per capita income.

3. Increase employment, especially at the sub-district level.

4. Reducing the flow of urbanization.

5. Fostering the spirit of ukhuwah Islamiyah through economic activities in order to increase per capita income towards an adequate quality of life.

BPRS business restrictions have been described in article 27 of BI Director Decree No. 32/36 / KEP / DIR / 1999, which are as follows: 
1. Collecting funds from the public in the form of deposits which include:

a. Savings based on the principle of wadiah or mudharabah.

b. Time deposits based on the mudharabah principle.

c. Another form that uses the principle of wadiah or mudharabah

2. Disbursing funds through:

a. Trading transactions based on the principles of mudharabah, istishna, ijarah, salam and other trading.

b. Profit sharing financing based on the principles of mudharabah, musyarakah, and other profit sharing financing.

c. Other financing based on the principles of rahn and qardh.

3. Carrying out other activities normally carried out by BPRS as long as it is approved by the National Sharia Board (DSN). For this reason, BPRS are prohibited from conducting business activities in foreign currencies, conducting capital participation, and are prohibited from conducting insurance business (Sudarsono, 2003: 88).

\section{Mudharabah}

Mudharabah is a business cooperation contract between the owner of the capital (shahibul maal) and the manager of the capital (mudharib). If the business that is carried out makes a profit, it will be divided (profit sharing) according to the agreement at the time of the contract, whereas if there is a financial loss, the owner of the capital will bear the loss and the fund manager will bear the loss of time, energy, and thoughts of what he has done. except mudarib negligent in carrying out his duties. Based on the authority granted by the owner of the funds, there are 2 (two) forms of mudharabah, namely Mudharabah Mutlaqah (Unrestricted Investment Account, URIA) and Mudharabah Muqayyadah (Restricted Investment Account, RIA).

\section{Mudharabah Deposit}

Time deposits are deposits whose withdrawals can only be made at certain times based on an agreement between the depository and the bank concerned. In the Fatwa of the National Syari'ah Council (NSC) No: 03 / DSN-MUI / IV / 2000, the justified sharia deposits are deposits based on the Mudharabah principle. In the fatwa, it is explained that deposits are time deposits whose withdrawals can only be made at a certain time based on an agreement between the depositing customer and the bank. In this sharia deposit, the customer acts as the owner of the fund (shahibul mal), while the Islamic bank acts as a fund manager (mudharib). Islamic banks can carry out various businesses as long as they do not conflict with sharia principles, including entering into mudharabah contracts with third parties.

\section{Profit-sharing}

Profit sharing is the profit sharing that is determined at the beginning of the formation of the contract in the form of a percentage of the agreement between the two parties (shahibul mal and mudharib). This profit-sharing figure is formed by bargaining, so the 
ratio used varies either 50:50, 60:40, 70:30, even 99: 1 , but jurisprudence experts agree that the ratio of 100: 0 is not allowed (Karim, 2004: 197).

The principle of profit sharing is divided into two, namely profit sharing and revenue sharing. In Islamic banking, no one uses the principle of profit sharing in calculating income distribution. The basic differences between profit sharing and loss sharing and revenue sharing are as follows:

1. In profit sharing, the revenue to be distributed is the net income after reducing the total cost to total revenue. Meanwhile, in revenue sharing, the revenue to be distributed is the gross income from fund distribution without having to be calculated in advance with the costs of operating the business.

2. The principle of profit and loss sharing, operational costs will be borne by the business capital or business income, meaning that costs will be borne by Shahibul Maal. Meanwhile, in the principle of ravenue sharing, the operational costs will be borne by the Islamic bank as the mudharib, namely the capital manager.

3. In the principle of profit and loss sharing, the distribution of income to be distributed is all income, both income from investment funds or income from fees for services provided by the bank after deducting all operational costs. Whereas in the principle of revenue sharing, the revenue to be distributed is only the income from the distribution of shahibul maal funds, while the fee income for services performed by Islamic banks is the bank's own pure income. From this fee income, Islamic banks can cover operational costs borne by Islamic banks.

The calculation for the profit sharing of mudharabah deposits is as follows:

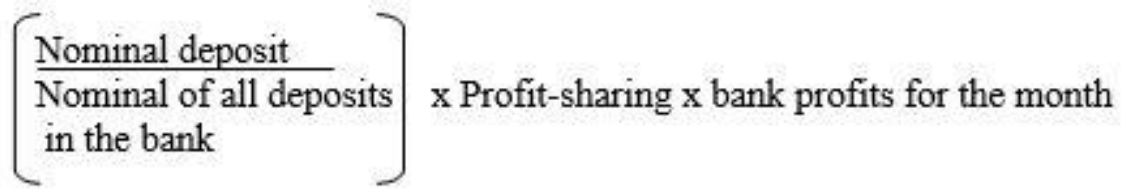

\section{ROA}

ROA is a profitability ratio that is used to measure a bank's ability with funds invested in assets and is used for bank operations to generate profits. So, ROA can be formulated as follows:

$$
\text { ROA }=\frac{\text { Net Profit }}{\text { total assets }} \times 100 \%
$$

Until now, all Islamic banking in Indonesia is still using the revenue sharing system with the concept of revenue sharing. In the principle of revenue sharing, the revenue that will be distributed is only the income from the distribution of shahibul maal funds, while the fee income for services carried out by Islamic banks is the bank's own pure income (Naf'an, 2011: 83). So there are many factors of assets on assets that influence the level of ROA. Therefore, ROA has no effect on the profit sharing rate of BPRS mudharabah deposits. 
FDR

FDR is a comparison between the financing provided by Islamic banks and the TPF that is successfully mobilized by the bank (Muhammad, 2002: 55). Then FDR is the ratio used to measure the liquidity of a bank in returning depositors' funds by relying on the financing provided as a source of liquidity. The FDR standard used by Bank Indonesia is $80 \%-110 \%$ (Amin, 2009: 41). The formula for finding FDR is as follows:

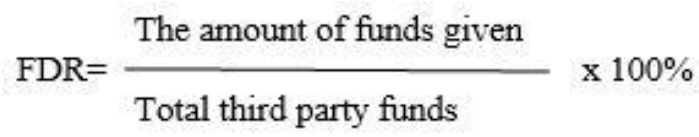

In its application to Islamic banking, banks will receive funds from Shahibul Mall in the form of Third Party Funds as a source of funds. These funds can be in the form of savings or mudharabah deposits with varying terms. Furthermore, the funds that have been collected are channeled back by the bank into earning assets. Then the profits from the distribution of this financing will be shared between the bank and the owner of deposits (Karim, 2004: 199). So when the DPK that enters the bank is considered high, there will also be a lot of funds available at the bank, which then the bank will finance a high amount which can be seen at a high FDR rate. The more financing made by the bank will increase the profit sharing on the financing made by the bank and will also increase the profit sharing given by the bank to customers who own deposits. Therefore, FDR has a positive effect on the profit sharing rate of mudharabah deposits (assuming banks are able to channel financing effectively).

NPF

NPF is financing whose collectability category is included in the criteria for substandard financing, doubtful financing, and non-performing financing (Dendawijaya, 2005: 68). Large amounts of problem financing will reduce the level of operation of these Islamic banks. If there is a decline in financing and profitability that is very severe, which affects the liquidity and profitability of Islamic banks, then customer confidence in the bank concerned will decline. An unreasonable NPF, one of which can cause a loss of opportunity to obtain income from the financing provided, thereby reducing profitability and adversely affecting bank profitability (Dendawijaya, 2009: 82). The formula for finding the NPF value is as follows:

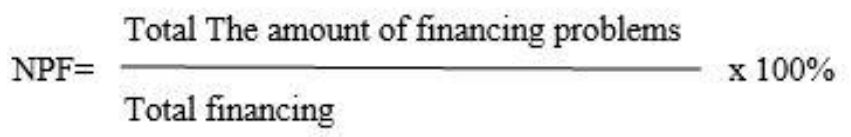

As explained, Mudharabah in its application to Islamic banking, namely banks will receive funds from shahibul mal in the form of third party funds as a source of funds. These funds can be in the form of savings or mudharabah deposits with varying terms. Furthermore, the funds that have been collected are channeled back by the bank into earning assets. Then the profits from the distribution of this financing will be shared between the bank and the owner of deposits. So when the NPF is high or the amount of bad financing occurs, the profit sharing that will be distributed to the bank will be low which also results in low profit sharing that will be distributed by the bank to customers

QE Journal | Vol.09 - No.01 - 41 
who have deposits. Therefore, NPF has a negative effect on the profit sharing rate of BPRS mudharabah deposit.

\section{RESEARCH METHOD}

In this study, researchers used quantitative research. In theory, quantitative researchers exclude and determine the changes and categories of variables that are bound in a hypothesis that often come before data.

The data source of this research comes from the financial reports of the Islamic People's Financing Bank (BPRS) which have been published by Bank Indonesia (BI) through the website www.bi.go.id. Data on the variables to be used are the financial ratios of the BPRS with details, namely: ROA, FDR, NPF, and the profit sharing of the BPRS mudharabah deposits. This study also uses time series data, namely data consisting of several time intervals. Researchers used data on variables related to the time span from January 2013 to April 2018.

The data analysis used in this research is multiple regression. This regression analysis model was chosen because it is a method commonly used to analyze the relationship between variables. Compared to simple regression, several problems will be encountered in multiple regression, so it is also necessary to do a diagnostic check or often called the classical assumption test and significance test, namely:

1. Normality Test

2. Multicollinearity Test

3. Heteroscedasticity Test

4. Autocorrelation Test

5. The t test

6. Test $F$

7. Coefficient of Determination

\section{RESULT AND DISCUSSION}

\section{ROA}

The results in this study obtained a value of $\beta_{1}$ of -45.830 with a significance value of 0.152 (greater than $\alpha=0.05$ ) and $t_{\text {count }}$ of 1.440 (less than $t_{\text {table }}=1.9929$ ). These results indicate that the ROA variable has no significant effect on the profit sharing variable of BPRS mudharabah deposits in Indonesia in 2012-2018.

The results of this study are in line with existing theories. The combined balance sheet of BPRS in the sharia banking statistics uploaded by Bank Indonesia (BI) shows indicators of assets, namely cash, placements with other banks, financing, other claims, istishna assets in progress, allowance for depreciation, fixed assets and inventory, and various assets. This shows that the level of ROA is influenced by many factors, not only from financing. In addition, until now all Islamic banks in Indonesia are still using the revenue sharing system with the concept of revenue sharing, which means that the revenue to be distributed is only the income from the distribution of shahibul maal funds, while the fee income for services performed by Islamic banks is the bank's own pure income.

$$
\text { QE Journal | Vol.09 - No.01 - } 42
$$


(Naf'an, 2011: 83). So it can be concluded that ROA has no effect on the profit sharing rate of BPRS mudharabah deposit.

The results of this study have different results from the research of Rahayu (2016) and Nofianti, et al (2015) which states that ROA has a positive and significant effect on mudharabah deposits. It has been described, this happens because with an increase in the income of Islamic banks, the profit sharing received by customers will also increase. With the increase in ROA, Islamic banks will continue to manage their income, one of which is by investing their profits in various activities that are considered to be beneficial to the company. Then the greater the bank makes a profit, the return for the results given to customers will also be even greater.

\section{FDR}

The results in this study obtained a value of $\beta_{3}$ of 5,620 with a significance value of 0,000 (less than $\alpha=0.05$ ) and $t_{\text {count }}$ of 4.071 (greater than $t_{\text {table }}=1.9929$ ). These results indicate that the FDR variable has a significant positive effect on the profit sharing variable of BPRS mudharabah deposit in Indonesia in 2012-2018.

The results of this study are in line with existing theories. Where mudharabah deposits are in practice, the deposits received by the bank will be channeled back into the form of earning assets. Then the profit on the financing will be shared between the bank and the owner of the DPK (Karim, 2004: 199). Therefore, when the incoming deposits are high, the financing made by the bank will also be high. For the amount of financing made by the bank, the profit sharing that will be received by the bank which will then be distributed to customers who have deposits of deposits will also be high, assuming that the bank can make financing effectively. So, FDR has a positive effect on the profit sharing rate of the BPRS mudharabah deposits. The results of this study are consistent with the research of Nofianti, et al (2015) and Khikmah (2015).

\section{NPF}

The results in this study obtained $\beta_{4}$ value of -29.576 with a significance value of 0.000 (less than $\alpha=0.05$ ) and $t_{\text {count }}$ of 4.398 (greater than $t_{\text {table }}=1.9929$ ). These results indicate that the NPF variable has a significant negative effect on the profit sharing variable of BPRS mudharabah deposits in Indonesia in 2012-2018 or in other words, receiving $\mathrm{H}_{\mathrm{a}}$ and money.

The results of this study are in line with existing theories. NPF is a ratio that shows bemasalah financing to the total financing provided by the bank. In fatwa Number 03 / DSN-MUI / IV / 2000 states that in their capacity as mudharib, banks can carry out various kinds of business that are not against sharia principles and develop them, including mudharabah with other parties. Mudharabah deposit in practice, deposits received by the bank will be channeled back into the form of earning assets. Then the profit on the financing will be shared between the bank and the owner of the DPK (Karim, 2004: 199). So when the high non-performing financing is reflected in the NPF, the profit sharing that will be received by the bank will be small and will result in low 
profit sharing received by customers who hold deposits. Therefore, NPF has a negative effect on the profit sharing rate of BPRS mudharabah deposit.

The results of this study support Amelia's research (2011) which states that if the asset quality reflected by the NPF increases, the effectiveness of bank income from the acquisition of assets will decrease and consequently will reduce the profit sharing of mudharabah deposits. However, the results of this study contradict Nofianti et al. (2015) who stated that NPF has no effect on profit sharing on deposits. This is because the demand for financing in banks is quite high, the handling of problematic financing at banks, and the small amount of Moral Hazard in banks (Novianti, 2015).

\section{CONCLUSIONS AND RECOMMENDATIONS}

\section{Conclusion}

Based on the results of data analysis and discussion in the previous chapter, the following conclusions were obtained:

1. Based on the results of the analysis, it shows that ROA has no significant effect on the profit sharing of BPRS mudharabah deposits in Indonesia for 2012-2018. This is because the profit sharing carried out by the BPRS is only for the accumulated income of the business carried out with capital from TPF without involving the personal income of the BPRS.

2. Based on the results of the analysis, it shows that the FDR has a significant positive effect on the profit sharing of BPRS mudharabah deposit in Indonesia in 2012-2018. This happens because when the DPK that enters the BPRS is considered high, the bank will also make high financing, which can be seen from the high FDR rate. When financing rises, the profit sharing that will be distributed to depositors' customers will also increase.

3. Based on the results of the analysis, it shows that the NPF has a significant negative effect on the profit sharing of BPRS mudharabah deposits in Indonesia in 2012-2018. This occurs because the BPRS has the right to conduct mudharabah with other parties, when there is a bad financing at the BPRS, it will reduce the profit sharing rate on mudharabah deposits.

4. ROA, FDR, and NPF together (simultaneously) have a significant effect on the profit sharing of mudharabah deposits. Then ROA, FDR, and NPF are factors that can affect the return on deposits.

\section{REFERENCES}

Badrun, Abdul Muid. 08 Desember 2015. Memajukan Perbankan Syariah. (Online). (https://www.republika.co.id/berita/koran/opini-koran/15/12/08/nz124r34memajukan-perbankan-syariah). Diakses 3 Juli 2018.

Dendawijaya, Lukman. 2005. Manajemen Perbankan. Jakarta: Ghalia Indonesia.

Dendawijaya, Lukman. 2009. Manajemen Perbankan. Jakarta: Ghalia Indonesia.

Fatwa Ulama Indonesia, Fatwa Dewan Syariah Nasional Majelis Ulama Indonesia Nomor 03/DSN-MUI/IV/2000 tentang Deposito.

QE Journal | Vol.09 - No.01 - 44 
Karim, Adiwarman. 2004. Bank Islam. Jakarta: PT RajaGrafindo Persada.

Lubis, Wajdi. 2012. Hukum Ekonomi Islam. Jakarta: Sinar Grafika.

Muhammad. 2002. Manajemen Bank Syariah. Yogyakarta: UPP AMP YKPN.Naf'an. 2014. Pembiayaan Musyarakah dan Mudharabah. Yogyakarta: GRAHA ILMU.

Rostanti, Qommarria. 2013. BPRS Andalkan Bagi Hasil Deposito. (Online). (https://www.republika.co.id/berita/ekonomi/syariahekonomi/13/03/14/mjn57m-bprs-andalkan-bagi-hasil-deposito). Diakses 3 Juli 2018.

Sudarsono. 2003. Bank \& Lembaga Keuangan Syariah. Yogyakarta: EKONISIA. 